\title{
Impacts of $\mathrm{CaO}$ solid particles in carbon dioxide absorption process from ship emission with $\mathrm{NaOH}$ solution
}

\author{
WANG Zhongcheng(王忠诚) ${ }^{1}$, LIU Xiaoyu (刘晓宇) ${ }^{1 *}$, ZHOU Peilin(周培林) ${ }^{2}, X U$ Leping(许乐平) ${ }^{1}$ \\ (1. Merchant Marine College, Shanghai Maritime University, Shanghai 201306, China; \\ 2. Naval Architecture Ocean and Marine Engineering College, University of Strathclyde, Glasgow G11XQ, UK)
}

\begin{abstract}
CO}_{2}$ emitted from ship exhaust is one of the major sources of atmospheric pollution. In order to reduce ship $\mathrm{CO}_{2}$ emissions, this paper comes up with the idea of recovering $\mathrm{CO}_{2}$ from ship exhaust by $\mathrm{NaOH}$ solution and improves the absorption rate by adding $\mathrm{CaO}$ solid particles. The effect mechanism of $\mathrm{CaO}$ solid particles on $\mathrm{CO}_{2}$ absorption efficiency is analyzed in detail, and the mathematical model is deduced and the $\mathrm{CaO}$ enhancement factor is calculated through experiments. Experiment result demonstrates that the effect of $\mathrm{CaO}$ solid particles on the absorption of $\mathrm{CO}_{2}$ in alkali solution is significant. The absorption rate of pure $\mathrm{CO}_{2}$ gas, the simulated ship exhaust gas and 6135AZG marine diesel engine emission can be increased by $10 \%$, $15.85 \%$ and $10.30 \%$, respectively. So it can be seen that $\mathrm{CaO}$ solid particles play an important role in improving the absorption efficiency of ship $\mathrm{CO}_{2}$ emission.
\end{abstract}

Key words: environmental protection, diesel emissions, $\mathrm{CO}_{2}$ absorption, $\mathrm{CaO}$ particulate matter, enhancement factor

CLC number: U 661

\section{Document code: $A$}

\section{O Introduction}

With the rapid development of the shipping industry, air pollution caused by marine diesel engine emissions draws more attention. The ship is a major means of transportation, producing a large quantity of $\mathrm{CO}_{2}$ emissions ${ }^{[1]}$. The International Convention for the Prevention of Pollution from Ships of 1973, as amended by the Protocol of 1978, adopted by the IMO Marine Environment Protection Committee (MEPC) at its 62nd meeting in July 2011, approved the Energy Efficiency Design (EEDI), Ship Energy Efficiency Management Plan (SEEMP) and other ship energy efficiency standards. According to the tacit acceptance procedure, the amendment was enforced in $2015^{[2]}$, imposing severe restrictions on ship $\mathrm{CO}_{2}$ emissions.

As the in-depth research on the effect of particulate matters on gas-liquid mass transfer, the concept of "enhancement factor" becomes popular, and the ratio of mass transfer rate between gas and liquid has been accepted ${ }^{[3]}$. Eq. (1) shows the definition of "enhancement factor".

Received date: 2017-04-07

Foundation item: Shanghai Science and Technology Committee (No.17170712100)

*E-mail address: liuxiaoyu@shmtu.edu.cn 


$$
A=\frac{J_{\text {act }}}{J_{\text {out }}},
$$

where $A, J_{\text {act }}$ and $J_{\text {out }}$ are manoeuvring indices; $A$ is the total enhancement factor; $J_{\text {act }}$ is the mass transfer rate with the solid particles; $J_{\text {out }}$ is the mass transfer rate without solid particles. Eq. (1) demonstrates the effect of particulate matters on gas-liquid two-phase mass transfer, which is much closer to the actual situation.

It was found that when adding slight solid particles into the gas-liquid reaction, the mass transfer efficiency could be improved significantly. After investigating the zero-order and first-order reaction processes of the vapor phase on catalyst surface in a stirred tank, Yuan et al. ${ }^{[4]}$ and Gutierrez et al. ${ }^{[5]}$ concluded that the stirring rate, gas feed rate, catalyst particle concentration, particle size and other elements could affect the enhancement factor directly. Wimmers et al. ${ }^{[6]}$ believed that there was a membrane at the gas interface in the activated carbon slurry and the solids concentration within the membrane area was much higher than that of the liquid phase. Liu et al. ${ }^{[7-9]}$ carried out the experiment that $\mathrm{CO}_{2}$ was absorbed by ethanolamine solution within filler absorption tower and the absorption rate could be improved by increasing alkali concentration or circulating fluid flow. Excessive chemicals will be consumed by purely increase the alkali concentration, and by just increasing the circulating fluid flow also led to higher energy consumption, neither economic nor environmental friendly. In this paper, we come up with the idea that by adding solid particles into the alkaline liquor to improve $\mathrm{CO}_{2}$ absorption efficiency in both chemical and physical aspects, reducing chemicals and energy consumption.

In this paper, a certain amount of $\mathrm{CaO}$ solid particles is added into the $\mathrm{NaOH}$ solution to increase the $\mathrm{CO}_{2}$ absorption rate. The enhancement mechanism of solid particles in the alkali decarburization is investigated, which provides the theoretical and experimental basis for improving solid particles decarburization.

\section{Solid Particles Mass Transfer Mechanism}

According to the current researches, scholars did not draw a unified conclusion about solid particles function mechanism in gas-liquid mass transfer, as the results from experiments were not quite the same. Below are some major theories about solid particles mass transfer mechanism:

(1) particles have only physical absorption on gases component in the gas-liquid mass transfer area; (2) particles catalyze in the chemical reactions involved in gas component; (3) particles react with gases to be transferred; (4) particles react with gases after getting dissolved in the gas-liquid mass transfer area; (5) particles work as the combinations of above four cases. This paper emphasizes on the mechanisms research synthesized (1) and (4) theories.

\subsection{Marine Alkaline Liquor Decarburization Mechanism}

When adding $\mathrm{CaO}$ into the alkaline decarburization solution, $\mathrm{Ca}(\mathrm{OH})_{2}$ will be generated immediately after $\mathrm{CaO}$ solid particles react with water. The reaction equation is shown in Eq. (2). 


$$
\mathrm{CaO}(\mathrm{s})+\mathrm{H}_{2} \mathrm{O}=\mathrm{Ca}(\mathrm{OH})_{2}(\mathrm{l}),
$$

After introduced into the alkaline solution, $\mathrm{CO}_{2}$ gas will react with $\mathrm{NaOH}$ and $\mathrm{Ca}(\mathrm{OH})_{2}$ solution. The reaction equation are

$$
\begin{gathered}
2 \mathrm{NaOH}(\mathrm{l})+\mathrm{CO}_{2}(\mathrm{~g})=\mathrm{Na}_{2} \mathrm{CO}_{3}(\mathrm{l})+\mathrm{H}_{2} \mathrm{O}, \\
\mathrm{Na}_{2} \mathrm{CO}_{3}(\mathrm{l})+\mathrm{Ca}(\mathrm{OH})_{2}(\mathrm{l})=\mathrm{CaCO}_{3}(\mathrm{~s}) \downarrow+2 \mathrm{NaOH} .
\end{gathered}
$$

That is, $2 \mathrm{NaOH}(\mathrm{l})+\mathrm{CaO}(\mathrm{s})+\mathrm{CO}_{2}(\mathrm{~g})=\mathrm{CaCO}_{3}(\mathrm{~s}) \downarrow+2 \mathrm{NaOH}(\mathrm{l})$.

From Eq. (4), $\mathrm{NaOH}$ can be regenerated and $\mathrm{NaOH}$ solution will be recycled, while $\mathrm{CaCO}_{3}$ is precipitated at the same time. Since the molecular weight of $\mathrm{Ca}(\mathrm{OH})_{2}$ is 74 and $\mathrm{CaCO}_{3}$ is 100 , the total amount of solid particles is almost constant throughout the experimental cycle.

\subsection{CaO Particles Enhanced Mechanism}

The $\mathrm{CO}_{2}$ absorption by $\mathrm{NaOH}$ solution with $\mathrm{CaO}$ solid particles is a mass transfer process accompanied with chemical reaction, both the chemical reaction mass transfer enhancement and physical enhanced particulate matter mass transfer happen during the reaction period.

1.2.1 Chemical enhancement mechanism Eqs. (5) and (6) show the kinetic model of liquid membrane reaction and diffusion ${ }^{[10-11]}$ in the reaction $\mathrm{CO}_{2}(\mathrm{~g})+\mathrm{Ca}(\mathrm{OH})_{2}(\mathrm{l}) \stackrel{k_{2}}{\longrightarrow} \mathrm{CaCO}_{3}(\mathrm{~s}) \downarrow+\mathrm{H}_{2} \mathrm{O}$.

The second order linear models are

$$
\begin{gathered}
\frac{\mathrm{d}^{2} c_{\mathrm{CO}_{2}}}{\mathrm{~d} x^{2}}=\frac{k_{2} c_{\mathrm{CO}_{2}} c_{\mathrm{Ca}(\mathrm{OH})_{2}}}{D_{\mathrm{CO}_{2}, \mathrm{~L}}}, \\
\frac{\mathrm{d}^{2} c_{\mathrm{Ca}(\mathrm{OH})_{2}}}{\mathrm{~d} x^{2}}=\frac{k_{2} c_{\mathrm{CO}_{2}} c_{\mathrm{Ca}(\mathrm{OH})_{2}}}{D_{\mathrm{Ca}(\mathrm{OH})_{2}, \mathrm{~L}}},
\end{gathered}
$$

where, $c_{\mathrm{CO}_{2}}, c_{\mathrm{Ca}(\mathrm{OH})_{2}}, D_{\mathrm{CO}_{2}, \mathrm{~L}}, k_{2}$ and $D_{\mathrm{Ca}(\mathrm{OH})_{2}, \mathrm{~L}}$ are manoeuvring indices; $c_{\mathrm{CO}_{2}}$ is the concentration of $\mathrm{CO}_{2}$ at the interface, $\mathrm{kmol} / \mathrm{m}^{3} ; \quad c_{\mathrm{Ca}(\mathrm{OH})_{2}}$ is the concentration of $\mathrm{Ca}(\mathrm{OH})_{2}$ at the interface, $\mathrm{kmol} / \mathrm{m}^{3} ; \quad D_{\mathrm{CO}_{2}, \mathrm{~L}}$ is the diffusion coefficient of $\mathrm{CO}_{2}$ in liquid phase, $\mathrm{m}^{2} / \mathrm{s} ; k_{2}$ is a reaction constant for the second stage, $\mathrm{m}^{3} /(\mathrm{kmol} \cdot \mathrm{s}) ; D_{\mathrm{Ca}(\mathrm{OH})_{2}, \mathrm{~L}}$ is the diffusion coefficient of $\mathrm{Ca}(\mathrm{OH})_{2}$ in liquid phase, $\mathrm{m}^{2} / \mathrm{s}$. When $x=0, c_{\mathrm{CO}_{2}}=c_{\mathrm{CO}_{2}, \mathrm{i}}\left(c_{\mathrm{CO}_{2}, \text { i }}\right.$ represents $\mathrm{CO}_{2}$ concentration, $\left.\mathrm{kmol} / \mathrm{m}^{3}\right), \frac{\mathrm{d} c_{\mathrm{Ca}(\mathrm{OH})_{2}}}{\mathrm{~d} x}=0$; when $x=\delta, \quad c_{\mathrm{Ca}(\mathrm{OH})_{2}}=c_{\mathrm{Ca}(\mathrm{OH})_{2}, \mathrm{~L}}$, where $\delta$ is the film thickness of reaction, $\mathrm{m}$.

Since the $\mathrm{Ca}(\mathrm{OH})_{2}$ concentration is almost constant during the reaction and involatile, therefore, the chemical enhancement factor can be expressed as below ${ }^{[12-13]}$.

$$
E=\frac{\sqrt{D_{\mathrm{CO}_{2}, \mathrm{~L}} k_{2} c_{\mathrm{Ca}(\mathrm{OH})_{2}, \mathrm{i}}}}{k_{\mathrm{L}}^{0}} / \tanh \left(\frac{\sqrt{D_{\mathrm{CO}_{2}, \mathrm{~L}} k_{2} c_{\mathrm{Ca}(\mathrm{OH})_{2}, \mathrm{i}}}}{k_{\mathrm{L}}}\right),
$$


where $E, \quad c_{\mathrm{Ca}\left(\mathrm{OH}_{2}, \mathrm{i}\right.}, k_{\mathrm{L}}^{0}$ and $k_{\mathrm{L}}$ are manoeuvring indices; $E$ is chemical enhancement factor; $c_{\mathrm{Ca}(\mathrm{OH})_{2}, \mathrm{i}}$ is concentration of $\mathrm{Ca}(\mathrm{OH})_{2}$ during the reaction period, $\mathrm{kmol} / \mathrm{m}^{3} ; k_{\mathrm{L}}^{0}$ is liquid phase mass transfer coefficient without chemical reaction, $\mathrm{kmol} /\left(\mathrm{m}^{2} \cdot \mathrm{s} \cdot \mathrm{kPa}\right) ; k_{\mathrm{L}}$ is liquid phase mass transfer coefficient with chemical reaction, $\mathrm{kmol} /\left(\mathrm{m}^{2} \cdot \mathrm{s} \cdot \mathrm{kPa}\right)$. Then the boundary conditions and integrate are brought into by combing Eqs. (5) and (6).

Then, the function model is

$$
(E-1) D_{\mathrm{CO}_{2}, \mathrm{~L}} c_{\mathrm{CO}_{2}, \mathrm{i}}=\frac{D_{\mathrm{Ca}(\mathrm{OH})_{2}, \mathrm{~L}}}{v}\left(c_{\mathrm{Ca}(\mathrm{OH})_{2}, \mathrm{~L}}-c_{\mathrm{Ca}(\mathrm{OH})_{2}, \mathrm{i}}\right),
$$

Finally, the function model is

$$
E=\frac{D_{\mathrm{Ca}(\mathrm{OH})_{2}, \mathrm{~L}}\left(c_{\mathrm{Ca}(\mathrm{OH})_{2} \mathrm{~L}}-c_{\mathrm{Ca}(\mathrm{OH}), \mathrm{i}}\right)}{v D_{\mathrm{CO}_{2}, \mathrm{~L}} c_{\mathrm{CO}_{2}, \mathrm{i}}}+1,
$$

where $v$ and $c_{\mathrm{Ca}(\mathrm{OH})_{2}, \mathrm{~L}}$ are manoeuvring indices; $v$ is the velocity of $\mathrm{CO}_{2}$ in the solution, $\mathrm{m} / \mathrm{s}$;

$c_{\mathrm{Ca}(\mathrm{OH})_{2}, \mathrm{~L}}$ is concentration of $\mathrm{Ca}(\mathrm{OH})_{2}$ solution, $\mathrm{kmol} / \mathrm{m}^{3}$;

$-D_{\mathrm{CO}_{2}, \mathrm{~L}} \frac{\mathrm{d} c_{\mathrm{CO}_{2}}}{\mathrm{~d} x}=(1-\delta) k_{2} c_{\mathrm{CO}_{2}, \mathrm{~L}} c_{\mathrm{Ca}(\mathrm{OH})_{2}, \mathrm{~L}}$.

1.2.2 Physical enhancement mechanism The physical enhancement is mainly about the mass transfer between gas and liquid. According to the dual-membrane theory ${ }^{[14-15]}$, it is necessary to meet the equilibrium state of the $A$ component at the gas-liquid interface, i.e., $C_{A, \mathrm{i}}=H p_{A, \mathrm{i}}$. Where $C_{A, \mathrm{i}}$ is $A$ component concentration in solution, $\mathrm{kmol} / \mathrm{m}^{3} ; H$ is $A$ component Henry coefficient, $\mathrm{m}^{3} \cdot \mathrm{kPa} / \mathrm{kmol} ; p_{A, \mathrm{i}}$ is $A$ component partial pressure in gas phase, $\mathrm{kPa}$. Since this study satisfies this condition, so the rate equation of $\mathrm{CO}_{2}$ diffused from the gas phase to the gas-liquid interface can be expressed below.

The first order linear model is

$$
-\frac{\mathrm{d} n_{\mathrm{CO}_{2}}}{\mathrm{~d} t}=\frac{D_{\mathrm{CO}_{2}, \mathrm{G}}}{\delta_{\mathrm{G}}}\left(p_{\mathrm{CO}_{2}, \mathrm{G}}-p_{\mathrm{CO}_{2}, \mathrm{i}}\right) S,
$$

where $D_{\mathrm{CO}_{2}, \mathrm{G}}, \quad \delta_{\mathrm{G}}, \quad p_{\mathrm{CO}_{2}, \mathrm{G}}, \quad p_{\mathrm{CO}_{2}, \mathrm{i}}$ and $S$ are manoeuvring indices; $D_{\mathrm{CO}_{2}, \mathrm{G}}$ is the diffusion coefficient of $\mathrm{Ca}(\mathrm{OH})_{2}$ in gas phase, $\mathrm{m}^{2} / \mathrm{s} ; \delta_{\mathrm{G}}$ is film thickness of $\mathrm{CO}_{2}$ in solution, $\mathrm{m}$; $p_{\mathrm{CO}_{2}, \mathrm{G}}$ is the pressure of $\mathrm{CO}_{2}$ in solution, $\mathrm{kPa} ; p_{\mathrm{CO}_{2}, \mathrm{i}}$ is the pressure of $\mathrm{CO}_{2}$ during the reaction period, $\mathrm{kPa} ; S$ is the solubility, $\mathrm{g}$.

The rate equation of the diffusion of $\mathrm{CO}_{2}$ components from the gas-liquid interface to the liquid phase is below.

The first order linear model is 


$$
-\frac{\mathrm{d} n_{\mathrm{CO}_{2}}}{\mathrm{~d} t}=\frac{D_{\mathrm{CO}_{2}, \mathrm{~L}}}{\delta_{\mathrm{L}}}\left(c_{\mathrm{CO}_{2}, \mathrm{i}}-c_{\mathrm{CO}_{2}, \mathrm{~L}}\right) S,
$$

where $\delta_{\mathrm{L}}$ is film thickness of liquid reaction, $\mathrm{m}$.

Combined with the definition of membrane transfer coefficient $k_{\mathrm{CO}_{2}, \mathrm{G}}=\frac{D_{\mathrm{CO}_{2}, \mathrm{G}}}{\delta_{\mathrm{G}}}$, $k_{\mathrm{CO}_{2}, \mathrm{~L}}=\frac{D_{\mathrm{CO}_{2}, \mathrm{~L}}}{\delta_{\mathrm{L}}}$. The first order linear model is

$$
N_{\mathrm{CO}_{2}}=K_{\mathrm{CO}_{2}, \mathrm{G}}\left(p_{\mathrm{CO}_{2}, \mathrm{G}}-p_{\mathrm{CO}_{2}}^{*}\right)=K_{\mathrm{CO}_{2}, \mathrm{~L}}\left(c_{\mathrm{CO}_{2}}^{*}-c_{\mathrm{CO}_{2}, \mathrm{~L}}\right) \text {, }
$$

where $N_{\mathrm{CO}_{2}}, k_{\mathrm{CO}_{2}, \mathrm{G}}, p_{\mathrm{CO}_{2}}^{*}, k_{\mathrm{CO}_{2}, \mathrm{~L}}, c_{\mathrm{CO}_{2}}^{*}$ and $c_{\mathrm{CO}_{2}, \mathrm{~L}}$ are manoeuvring indices; $N_{\mathrm{CO}_{2}}$ is physical enhancement factor; $k_{\mathrm{CO}_{2}, \mathrm{G}}$ is gas phase mass transfer coefficient of $\mathrm{CO}_{2}$, $\mathrm{kmol} /\left(\mathrm{m}^{2} \cdot \mathrm{s} \cdot \mathrm{kPa}\right) ; p_{\mathrm{CO}_{2}}^{*}$ is the equilibrium pressure of $\mathrm{CO}_{2}$ in solution, $\mathrm{kPa} ; k_{\mathrm{CO}_{2}, \mathrm{~L}}$ is liquid phase mass transfer coefficient of $\mathrm{CO}_{2}, \mathrm{kmol} /\left(\mathrm{m}^{2} \cdot \mathrm{s} \cdot \mathrm{kPa}\right) ; c_{\mathrm{CO}_{2}}^{*}$ is the equilibrium concentration of $\mathrm{CO}_{2}$ in solution, $\mathrm{kmol} / \mathrm{m}^{3} ; \quad c_{\mathrm{CO}_{2}, \mathrm{~L}}$ is concentration of $\mathrm{CO}_{2}$ in solution, $\mathrm{kmol} / \mathrm{m}^{3}$;

$$
K_{\mathrm{CO}_{2}, \mathrm{G}}=\frac{1}{\frac{1}{k_{\mathrm{CO}_{2}, \mathrm{G}}}+\frac{1}{H k_{\mathrm{CO}_{2}, \mathrm{~L}}}} ; K_{\mathrm{CO}_{2}, \mathrm{~L}}=\frac{1}{\frac{H}{k_{\mathrm{CO}_{2}, \mathrm{G}}}+\frac{1}{k_{\mathrm{CO}_{2}, \mathrm{~L}}}} \text {. }
$$

The total mass transfer resistance during the reaction process is the sum of the mass transfer resistance and the mass transfer resistance of the liquid phase ${ }^{[16]}$. The total mass transfer rate is the ratio of the total mass transfer $\left(y-y^{*}\right)$ to the total mass transfer resistance $\left(1 / K_{y}\right)$, and regarding dilution solution, the equilibrium relationship between the dilute solution and the system is subject to Henry's law ${ }^{[17]} y^{*}=m x$, where $y$ is molar concentration ratio of the gas phase; $y^{*}$ molar concentration ratio of the gas phase balanced with it's of the liquid phase; $m$ is equilibrium constant; $x$ is molar concentration ratio of the liquid phase; $K_{y}$ is total mass transfer coefficient driven by $\left(y-y^{*}\right), \mathrm{kmol} /\left(\mathrm{m}^{2} \cdot \mathrm{s} \cdot \mathrm{kPa}\right)$.

$$
\text { From the gas phase: } \frac{N_{\mathrm{CO}_{2}}}{k_{y}}=\left(y-y_{i}\right) \text { and liquid phase: } \frac{N_{\mathrm{CO}_{2}} m}{k_{x}}=\left(y_{i}-y^{*}\right) \text {, where } k_{y}
$$
is mass transfer coefficient of the gas phase, $\mathrm{kmol} /\left(\mathrm{m}^{2} \cdot \mathrm{s} \cdot \mathrm{kPa}\right) ; k_{x}$ is mass transfer coefficient of the liquid phase, $\mathrm{kmol} /\left(\mathrm{m}^{2} \cdot \mathrm{s} \cdot \mathrm{kPa}\right) ; y_{i}$ is molar concentration ratio of the gas phase during the reaction period; So we can conclude the result in Eq. (13) 


$$
N_{\mathrm{CO}_{2}}=\frac{\left(y-y_{i}\right)+\left(y_{i}-y^{*}\right)}{\frac{1}{k_{y}}+\frac{m}{k_{x}}}=\frac{y-y^{*}}{\frac{1}{k_{y}}+\frac{m}{k_{x}}} .
$$

From the differ phase: $N_{\mathrm{CO}_{2}}=\frac{y-y^{*}}{1 / K_{y}}=K_{y}\left(y-y^{*}\right)$ and by comparison: $\frac{1}{K_{y}}=\frac{1}{k_{y}}+\frac{m}{k_{x}}$, the total mass transfer rate equation is calculated in terms of gas phase ${ }^{[18]}$, so the physical enhancement factor can be expressed.

The function model is

$$
N_{\mathrm{CO}_{2}}=\left(\frac{1}{\frac{1}{H k_{\mathrm{CO}_{2}, \mathrm{~L}}}+\frac{1}{k_{\mathrm{CO}_{2}, \mathrm{G}}}}\right)\left(p_{\mathrm{CO}_{2}, \mathrm{G}}-p_{\mathrm{CO}_{2}}{ }^{*}\right) .
$$

Therefore, the total enhancement factor of $\mathrm{CaO}$ particles is the sum of the chemical enhancement factor, Eq. (9), and the physical enhancement factor, Eq. (14).

Finally, the function model is

$$
A=E+N_{\mathrm{CO}_{2}}
$$

\section{Experimental Condition}

The main purpose of this experiment is to study the effect of solid particles on marine alkaline liquor decarburization; Figure 1 shows the experimental process.

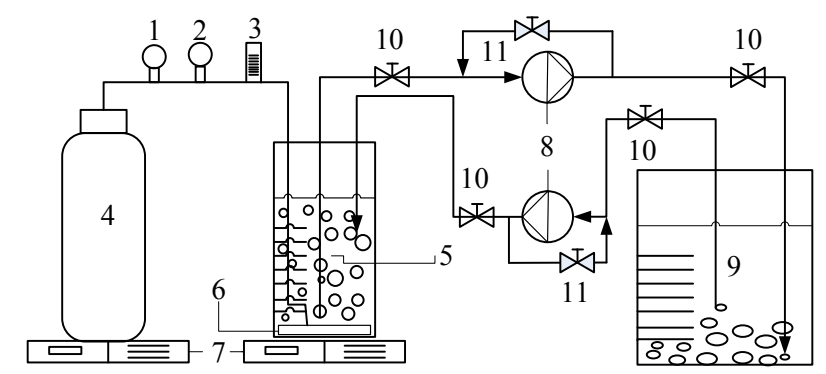

1- Reducing valve, 2-Pressure gauge, 3-Flowmeter, 4- $\mathrm{CO}_{2}$ cylinder, 5-Reactor, 6-Diffusor, 7-High-precision scale, 8-Gear pump, 9-Reservoir, 10-Regulate valve, 11-Bypass valve

Fig. 1 Facilities for marine alkaline liquor decarburization

As shown in Fig. 1, gas stored in the cylinder $\left(\mathrm{CO}_{2}\right.$ or ship simulated gas) is decompressed by reducing valve and regulated to the pressure that slightly higher than atmospheric pressure (0.103 MPa), then adjusted to an appropriate flow rate through flow meter 3, finally entered into the reactor 5 through the diffuser 6 . In order to achieve a better absorption effect, it is necessary to limit the size of air bubble before entering the solution. High-precision scale 7 on the bottom is applied to measure the mass reduction of cylinder 4 and mass increment of reactor 5. Gear pump 8 keeps the whole system circulated. The diameter of the reaction vessel is $120 \mathrm{~mm}$; solution's height is $240 \mathrm{~mm}$; and the weight is $3 \mathrm{~kg}$; the initial reaction temperature is $25{ }^{\circ} \mathrm{C}$; diffuser's diameter is $104 \mathrm{~mm}$; gas flow rate is $1 \mathrm{~L} / \mathrm{min}$; the experiment lasts $30 \mathrm{~min}$; sample is took every 2 $\min$. 


\subsection{Gas Used for the Experiment}

The experiment uses three kinds of gas, namely pure $\mathrm{CO}_{2}$, simulated exhaust and diesel engine exhaust. The pure $\mathrm{CO}_{2}$ is $99 \%$ purity gas produced by Shanghai Special Gas Co., Ltd. The simulated exhaust gas is applied in the experiment which is based on the exhaust gas data from 6S35 ME-B produced by MAN B\&W Company. The diesel engine exhaust comes from MAN Shanghai Diesel Engine Co., Ltd and the simulating exhaust gas consists of $\mathrm{N}_{2}, \mathrm{O}_{2}, \mathrm{CO}_{2}$ and $\mathrm{SO}_{2}$ with the mass fraction of $80.09 \%, 15.18 \%, 4.69 \%$ and $0.04 \%$, respectively.

\subsection{Experimental Chemicals}

During the study, $\mathrm{NaOH}$ solid and $\mathrm{CaO}$ solid are used, the specific parameters are shown in Table 1.

Table1 $\mathrm{NaOH}$ solid and $\mathrm{CaO}$ solid specific parameters

\begin{tabular}{cccccc}
\hline & \multicolumn{2}{c}{ Solid $\mathrm{NaOH}$ (flake $)$} & \multicolumn{3}{c}{ Calcium oxide (CaO particles) } \\
\hline Charity test & Qualified & $\mathrm{AL}$ & $\leqslant 0.002 \%$ & $\mathrm{Cl}$ & $\leqslant 0.01 \%$ \\
Total nitrogen $(\mathrm{N})$ & $\leqslant 0.001 \%$ & $\mathrm{~K}$ & $\leqslant 0.05 \%$ & Sulfate $\left(\mathrm{SO}_{4}\right)$ & $\leqslant 0.1 \%$ \\
Chloride $(\mathrm{Cl})$ & $\leqslant 0.005 \%$ & $\mathrm{Ca}$ & $\leqslant 0.01 \%$ & Loss on ignition & $\leqslant 2.0 \%$ \\
Sulfate $\left(\mathrm{SO}_{x}\right)$ & $\leqslant 0.005 \%$ & $\mathrm{Fe}$ & $\leqslant 0.001 \%$ & $\mathrm{Fe}$ & $\leqslant 0.015 \%$ \\
Phosphate $\left(\mathrm{PO}_{x}\right)$ & $\leqslant 0.001 \%$ & Carbonate & $\leqslant 1.5 \%$ & Alkali and magnesium & $\leqslant 0.5 \%$ \\
& & $\left(\mathrm{Na}_{2} \mathrm{CO}_{3}\right)$ & & Heavy metal $(\mathrm{Pb})$ & $\leqslant 0.005 \%$ \\
Heavy metal $(\mathrm{Pb})$ & $\leqslant 0.003 \%$ & Content $(\mathrm{NaOH})$ & $\geqslant 96 \%$ & Acetic acid insoluble matter & $\leqslant 0.05 \%$ \\
& & & & CaO content & $\geqslant 98.0 \%$ \\
& & & & Particles volume & $\leqslant 0.3 \mathrm{~mm}$ \\
\hline
\end{tabular}

\subsection{Measuring Instrument}

Measuring instruments include 2 pieces of high-precision ACS-258 electronic scales, 1 piece of JJ324BC balance and 1 piece of MP512-02 $\mathrm{pH}$ meter. The maximum range and accuracy of the high-precision electronic scales are $15 \mathrm{~kg}$ and $0.1 \mathrm{~g}$, similarly the $\mathrm{pH}$ meter is $14.00 \mathrm{pH}$ and \pm 0.002 .

\section{Experimental Results and Analysis}

In order to analyze the effect of solid particles on $\mathrm{CO}_{2}$ absorption, pure $\mathrm{CO}_{2}$ gas is first introduced to $\mathrm{NaOH}$ solution, then to the mixed $\mathrm{NaOH}$ solution with $\mathrm{CaO}$ particles, finally the simulated ship exhaust gas is used for verification. $\mathrm{CO}_{2}$ absorbance rate is the ratio of the mass of absorbed $\mathrm{CO}_{2}$ to the total mass of $\mathrm{CO}_{2}$ that enters the liquid, expressed as a percentage.

\subsection{Study on CaO Enhancement Factor}

In order to investigate the enhancement factor of $\mathrm{CaO}$ solid particles, $2.5 \mathrm{~g}, 1.25 \mathrm{~g}, 0.75 \mathrm{~g}$, $0.375 \mathrm{~g}, 0.1875 \mathrm{~g}$ and $0.0938 \mathrm{~g}$ of $\mathrm{CaO}$ solid particles are used for the test respectively. It is found that when the mass of $\mathrm{CaO}$ exceeds $2.5 \mathrm{~g}$, a large amount of $\mathrm{Ca}(\mathrm{OH})_{2}$ particles will precipitate and obstruct the gas release, which is disadvantageous to $\mathrm{CO}_{2}$ absorption. Therefore, this experiment takes the weight of $2.5 \mathrm{~g}$ as maximum, and halves the weight successively to explore the enhancement functions of $\mathrm{CaO}$. Figure 2 shows the experimental results. 


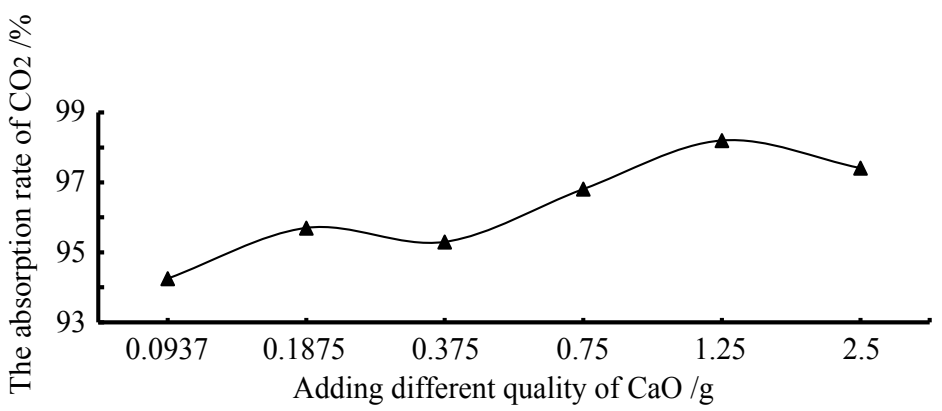

Fig. $2 \mathrm{CO}_{2}$ absorption rate varies with $\mathrm{CaO}$ weight

It can be seen from Fig. 2 that the average $\mathrm{CO}_{2}$ absorption rate is $94.25 \%$ with $0.0937 \mathrm{~g} \mathrm{CaO}$. As $\mathrm{CaO}$ increases continuously, the absorption rate also increases, indicating that the more particles, the more favorable of gas-liquid mass transfer. However, the average $\mathrm{CO}_{2}$ absorption rate reaches the maximum value of $98.2 \%$ when $\mathrm{CaO}$ 's weight reaches to $1.25 \mathrm{~g}$. After increasing the weight of $\mathrm{CaO}$ to $2.5 \mathrm{~g}$, the absorption rate slightly decreases to $97.41 \%$, which means that $\mathrm{CaO}$ solid particles does improve the $\mathrm{CO}_{2}$ absorption within a certain limit. When the mole ratio of $\mathrm{NaOH}$ to $\mathrm{CaO}$ is 135 , the absorption of $\mathrm{CO}_{2}$ in $\mathrm{NaOH}$ solution reaches the maximum, and the enhancement factor $A$ is 1.1 .

Through observation, $\mathrm{Ca}(\mathrm{OH})_{2}$ particles play two main roles: first role is to prevent bubble polymerization. When $\mathrm{CO}_{2}$ is introduced into the solution, chaotic circulation occurs, $\mathrm{Ca}(\mathrm{OH})_{2}$ particles are rapidly shuttled among the $\mathrm{CO}_{2}$ bubbles and inhibit the bubbles polymerization; second role is to improve the adsorption effect. $\mathrm{Ca}(\mathrm{OH})_{2}$ particles circulate in the solution with a certain amount of micro $\mathrm{CO}_{2}$ bubbles adsorbed on their surface, which reduces the amount of bubbles escaping from the liquid surface and increases the residence time.

\subsection{The Effect of $\mathrm{CO}_{2}$ Absorption Rate from Pure $\mathrm{CO}_{2}$}

In order to study the effect of solid particles on ship's decarburization, a contrast experiment is carried out with pure $\mathrm{NaOH}$ solution and mixed $\mathrm{NaOH}$ solution with $\mathrm{CaO}$ solid particles. The concentration of $\mathrm{NaOH}$ solution is $1 \mathrm{~mol} / \mathrm{L}$, the total volume is $3 \mathrm{~L}$, and $\mathrm{CaO}$ 's weight is $1.25 \mathrm{~g}$. Figure 3 shows the $\mathrm{CO}_{2}$ absorption rate varies with time.

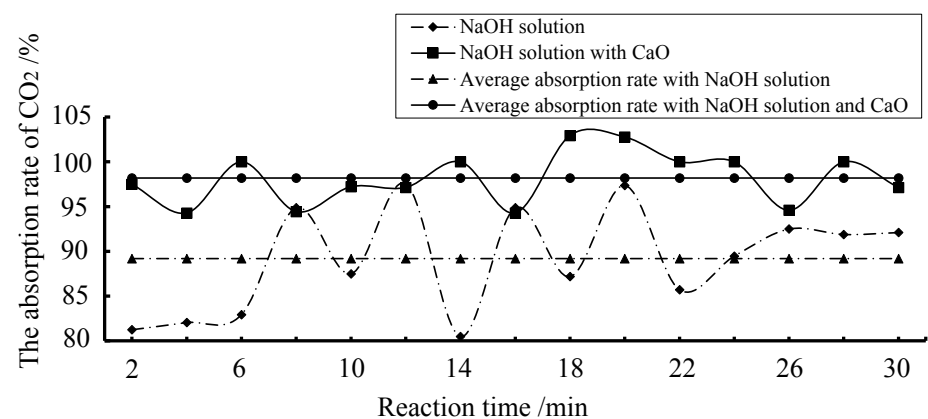

Fig. $3 \mathrm{CO}_{2}$ absorption rate varies with time before and after adding $\mathrm{CaO}$ particles

It can be seen from Fig. 3 that the average $\mathrm{CO}_{2}$ absorption rate is $89.2 \%$ without $\mathrm{CaO}$ and increases by $10 \%$ to $98.2 \%$ after adding $\mathrm{CaO}$, which means that $\mathrm{CaO}$ particulate matters can improve the $\mathrm{CO}_{2}$ absorption rate significantly. Because $\mathrm{CaO}$ is an alkaline substance, after reacting with water, it turns into $\mathrm{Ca}(\mathrm{OH})_{2}$, which has a certain chemical absorption to $\mathrm{CO}_{2}$, will be generated rapidly. However, the amount of $\mathrm{CaO}$ added in this experiment is only $1.25 \mathrm{~g}, 0.0307$ 
mol, compared with $3 \mathrm{~mol} \mathrm{NaOH}$ solution, the difference of alkalinity is nearly 100 times. During the experiment, the average reaction temperature is $27.5^{\circ} \mathrm{C}$. The relationship between solubility and the temperature of $\mathrm{Ca}(\mathrm{OH})_{2}{ }^{[19]}$ shows that the solubility of $\mathrm{Ca}(\mathrm{OH})_{2}$ is $0.156 \mathrm{~g}$ at $27.5{ }^{\circ} \mathrm{C}$, so there is only $0.468 \mathrm{~g} \mathrm{Ca}(\mathrm{OH})_{2}$ dissolved in the mixed solution. From Eq. (3), it can be seen that $\mathrm{CaCO}_{3}$ precipitates during the reaction process, and it also participates in the reaction, so the mass of the solid particles changes little during the whole cycle. After adding $1.25 \mathrm{~g} \mathrm{CaO}$ solid particles, the $\mathrm{CO}_{2}$ absorption rate is increased by $10 \%$ because of the physical effects.

\subsection{The Effect of $\mathrm{CO}_{2}$ Absorption Rate from Simulated Exhaust Gas}

Exhaust gas composition of diesel engines is affected by many factors, such as the type of diesel engine, fuel quality, ship operating conditions, etc. Based on the exhaust gas from 6135AZG diesel engine, the representative contents of exhaust gas are selected as $\mathrm{N}_{2}, \mathrm{O}_{2}, \mathrm{CO}_{2}$ and $\mathrm{SO}_{2}$ with mass fraction $80.09 \%, 15.18 \%, 4.69 \%$ and $0.04 \%$ respectively. The simulated exhaust gas is first introduced to the pure $\mathrm{NaOH}$ solution, then $1.5 \mathrm{~g} \mathrm{CaO}$ was added into the $\mathrm{NaOH}$ solution with same concentration. Since the acidity of $\mathrm{SO}_{2}$ is stronger than $\mathrm{CO}_{2}$, so $\mathrm{SO}_{2}$ is assumed to be absorbed completely. Figure 4 shows the absorption rate of $\mathrm{CO}_{2}$ contrast.

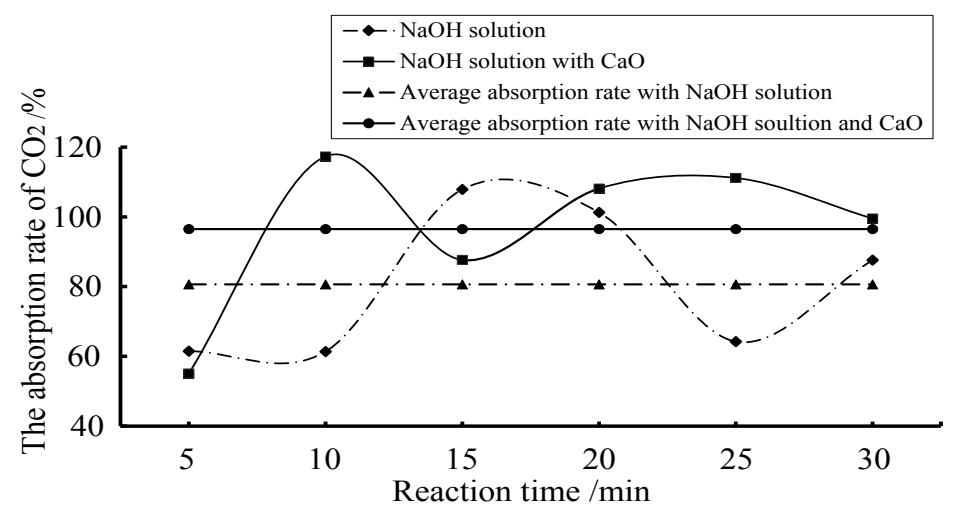

Fig. $4 \mathrm{CO}_{2}$ absorption rate varies with time before and after adding $\mathrm{CaO}$ to simulated exhaust

We can see that $\mathrm{CO}_{2}$ content in the simulated exhaust gas is lower than that of pure $\mathrm{CO}_{2}$ gas, so the curve fluctuates wildly but the overall trend of the two absorption curves is about the same, and the main difference is the first half of the reaction, which achieves a better absorption effect due to the presence of solid particles. The average absorption rate of simulated exhaust gas is $80.65 \%$ without $\mathrm{CaO}$ solid particles and it increases by $15.85 \%$ to $96.50 \%$ after adding $\mathrm{CaO}$ solid particles. It can be seen that neither pure $\mathrm{CO}_{2}$ gas, simulated exhaust gas nor $\mathrm{CaO}$ solid particulates can improve $\mathrm{CO}_{2}$ absorption significantly, and the trend of both charts is very similar.

\subsection{Experimental with Marine Diesel Engine of 6135AZG}

Based on the 6135AZG marine diesel engine, running under load $L$ characteristics condition at the speed of $1500 \mathrm{r} \cdot \mathrm{min}^{-1}$, the engine operating points and the theoretical displacement are shown in Table 2.

Table 2 Diesel engine load characteristics of $6135 \mathrm{AZG}$

\begin{tabular}{ccccccc}
\hline $\begin{array}{c}\text { Working } \\
\text { condition }\end{array}$ & $\begin{array}{c}\text { Load ratio } \\
/ \%\end{array}$ & $\begin{array}{c}\text { Fuel consumption } \\
/ \mathrm{g} \bullet(\mathrm{kW} \bullet \mathrm{h})^{-1}\end{array}$ & $\begin{array}{c}\text { Power } \\
/ \mathrm{kW}\end{array}$ & $\begin{array}{c}\text { Torque } \\
/(\mathrm{N} \bullet \mathrm{m})\end{array}$ & $\begin{array}{c}\text { Theoretical } \\
\text { displacement } \\
/\left(\mathrm{m}^{3} \bullet \mathrm{h}^{-1}\right)\end{array}$ & $\begin{array}{c}\text { Theoretical } \\
\text { displacement of } \mathrm{CO}_{2} \\
/\left(\mathrm{kg} \bullet \mathrm{h}^{-1}\right)\end{array}$ \\
\hline 1 & $100 \%$ & 225.8 & 162.0 & 1031.40 & 3414.57 & 103.84
\end{tabular}




$\begin{array}{lllllll}2 & 75 \% & 227.0 & 121.5 & 773.55 & 2814.05 & 86.89 \\ 3 & 50 \% & 236.0 & 81.0 & 515.70 & 1950.45 & 60.24 \\ 4 & 25 \% & 252.0 & 40.5 & 257.85 & 1040.73 & 32.12\end{array}$

The exhaust gas outlet temperature is $55{ }^{\circ} \mathrm{C}$ after cooling, and other test conditions remain unchanged. Figure 5 shows the test results.

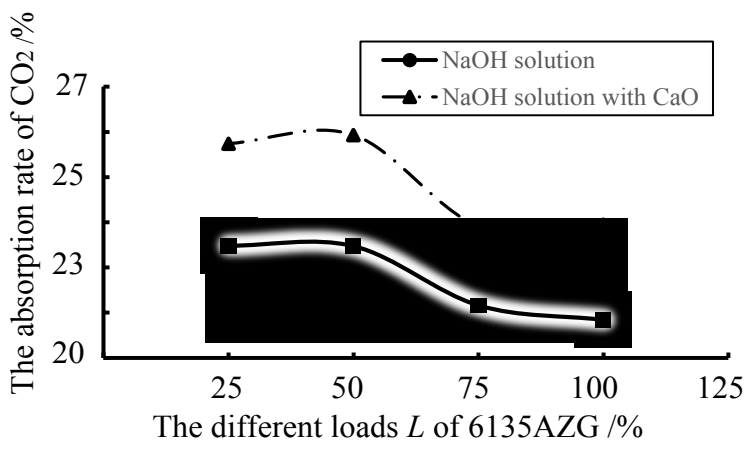

Fig. $5 \mathrm{CO}_{2}$ absorption rate varies with time before and after adding $\mathrm{CaO}$ to simulated exhaust

From Fig. 5 we can see that when the 6135AZG marine diesel engine runs at $25 \%$ load, the exhaust gas $\mathrm{CO}_{2}$ absorption rate is $22.48 \%$ in pure $\mathrm{NaOH}$ solution. It falls to $22.47 \%, 21.16 \%$ and $20.84 \%$ at $50 \%, 75 \%$ and $100 \%$ load respectively. After adding $\mathrm{CaO}$ solid particles into the solution, the exhaust gas $\mathrm{CO}_{2}$ absorption rate rises to $24.74 \%, 24.93 \%, 22.92 \%$ and $22.95 \%$ at $25 \%, 50 \%, 75 \%$ and $100 \%$ load respectively.

\subsection{The Varies of pH Value on Absorption Solution in Experiment}

In the experiment, we find that the $\mathrm{pH}$ value obtained by using simulated exhaust of a ship distribution trend is in good agreement with the experiment of 6135AZG marine diesel engine. In other words, the $\mathrm{pH}$ value reduction of $\mathrm{NaOH}$ solution with $\mathrm{CaO}$ solid is slower than the purity $\mathrm{NaOH}$ solution, as shown in Fig. 6.

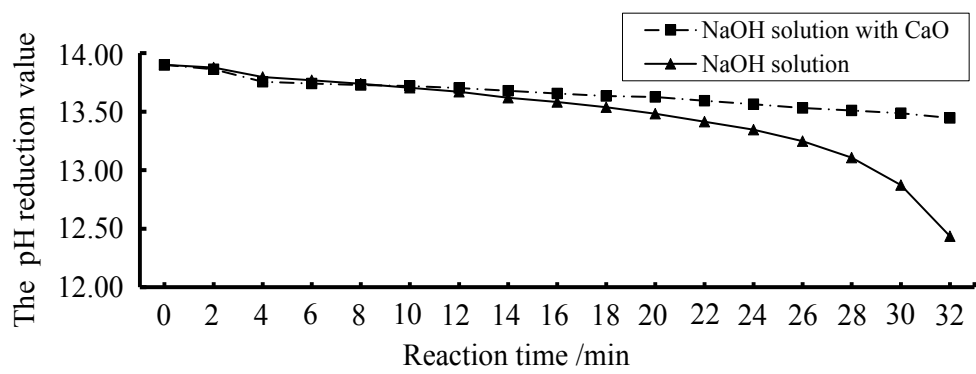

Fig. 6 The $\mathrm{pH}$ reduction varies with time using simulated gas and real gas in experiment

At the beginning of the experiment, the $\mathrm{pH}$ of $\mathrm{NaOH}$ solution with $\mathrm{CaO}$ is lower than the purity $\mathrm{NaOH}$ solution at 13.88 . And the $\mathrm{pH}$ values of the two solutions are different in the 14th minute, the $\mathrm{pH}$ value of $\mathrm{NaOH}$ solution with $\mathrm{CaO}$ is 13.70 , while the $\mathrm{NaOH}$ solution $\mathrm{pH}$ value is 13.67.

The $\mathrm{pH}$ value of $\mathrm{NaOH}$ solution with $\mathrm{CaO}$ is 13.56 , and the $\mathrm{pH}$ value of the purity $\mathrm{NaOH}$ solution is 13.35 when the experiment lasts for 24 minutes. The $\mathrm{pH}$ value of $\mathrm{NaOH}$ solution with $\mathrm{CaO}$ is 13.44 , the $\mathrm{pH}$ of $\mathrm{NaOH}$ solution is 12.44 when the experiment lasts for 32 minutes. After the reaction completes, the result shows that the $\mathrm{pH}$ value of $\mathrm{NaOH}$ solution with $\mathrm{CaO}$ decrease by 0.44 , while the $\mathrm{pH}$ value of the purity $\mathrm{NaOH}$ solution is down by 1.46 . 


\subsection{The Comparison of $\mathrm{CO}_{2}$ Absorption Rate in $\mathrm{NaOH}$ Solution with and without $\mathrm{CaO}$ Particles}

When the mole ratio of $\mathrm{NaOH}$ to $\mathrm{CaO}$ is 135 in the mixed solution. The $\mathrm{CO}_{2}$ absorption rate reaches to $98.2 \%$ to pure $\mathrm{CO}_{2}$ gas, $10 \%$ higher than the pure $\mathrm{NaOH}$ solution, the $\mathrm{CO}_{2}$ absorption rate of the simulated exhaust gas also increases by $15.85 \%$ from $80.65 \%$ to $96.5 \%$. The $\mathrm{CO}_{2}$ absorption rate from $6135 \mathrm{AZG}$ diesel engine emission also increases by $10.30 \%$ from $21.74 \%$ to $23.89 \%$, as shown in Fig. 7 .

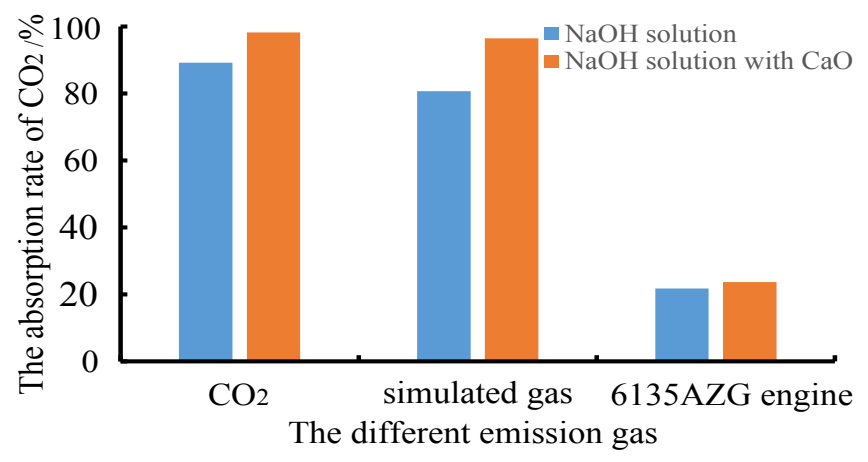

Fig. $7 \mathrm{CO}_{2}$ absorption rate varies before and after adding $\mathrm{CaO}$ to the different gas

\section{Conclusion}

In this paper, the method of adding $\mathrm{CaO}$ solid particles into $\mathrm{NaOH}$ solution is proposed to improve $\mathrm{CO}_{2}$ absorption efficiency. The $\mathrm{CaO}$ particles enhancement mechanism is expounded from both chemical and physical aspects. The mathematic enhancement model was derived and the enhancement effect have been verified through the experiment. The experimental result shows that there is a micro bubbles accumulation process during the $\mathrm{CO}_{2}$ absorption process without adding $\mathrm{CaO}$ in the solution and the absorption effect will gradually increase as the micro bubbles form a circulation in the upper part of the reactor, and the average absorption rate can reach the highest level of $89.2 \%$, which is far to achieve the desired value. While, the absorption efficiency improves significantly after adding $\mathrm{CaO}$ solid particles. So we can conclude that adding $\mathrm{CaO}$ particles into the $\mathrm{NaOH}$ solution can improve $\mathrm{CO}_{2}$ absorption significantly and it has a promising future in the ship exhaust gas handling area.

Acknowledgement The author thanks to my tutors Professor Xu Leping and Zhou Peilin, the project team and my family.

\section{References}

[1] WANG Z C, ZHOU P L, XU L P, et al. Experimental study of $\mathrm{CO}_{2}$ absorption by $\mathrm{NaOH}$ solution[J]. Journal of Safety and Environment, 2015,15(4):293-296(in Chinese).

[2] PENG C S. Discussion on the "Limits and verification methods of $\mathrm{CO}_{2}$ emissions from 
operating vessels" [J]. Marine Technology, 2013,(1):67-69(in Chinese).

[3] HU X W. Study on the effect of adsorbent particles and pollutants on $\mathrm{CO}_{2}$ absorption[D]. Tianjin: Tianjin University, 2008(in Chinese).

[4] YUAN G, KEANE M A. Liquid phase catalytic hydrodechlorination of 2, 4-dichlorophenol over carbon supported palladium: an evaluation of transport limitations[J]. Chemical Engineering Science, 2003,58(2):257-267.

[5] GUTIERREZ-ORITIZ J I, LOPEZ-FONSECA R. Mass transfer studies in the hydrogenation of methyl oleate over a $\mathrm{Ni} / \mathrm{SiO}_{2}$ catalyst in the liquid phase[J]. Reaction Kinetics, Mechanisms and Catalysis, 2000,70(2):341-348.

[6] WIMMERS O J, FORTUIN J M H. The use of adhesion of catalyst particles to gas bubbles to achieve enhancement of gas absorption in slurry reactors- I . Investigation of particle-to-bubble adhesion using the bubble pick-up method[J]. Chemical Engineering Science, 1988,43(2):303-312.

[7] LIU Y S, WEI G F, ZHANG $\mathrm{H}$. Enhancement factor of $\mathrm{CO}_{2}$ absorption by ethanolamine aqueous solution in packed tower[J]. Journal of Chemical Industry and Engineering, 2014, 65(8):3054-3061(in Chinese).

[8] NA Y Q, FU K Y, LIANG Z W, et al. Mass transfer performance in a $\theta$-ring packed tower for $\mathrm{CO}_{2}$ absorption process using MEA[J]. Journal of Hunan University: Natural Sciences, 2011, 38(3): 69-72(in Chinese).

[9] SHEN F Z, GUO S H, ZHOU H R. Waste carbon dioxide recovering methods and utilized ways[J]. Guangdong Chemical Industry, 2013,40(23):136-138(in Chinese).

[10] JOOSTEN G E H, DANCKWERTS P V. Chemical reaction and effective interfacial areas in gas absorption[J]. Chemical Engineering Science, 1973,28(2): 453-461.

[11] JIA S Y, CHAI C J. Chemical Mass Transfer and Separation Process (2nd Edition) [M], Shanghai: Chemical Industry Press, 2010(in Chinese).

[12] TANG Z L, ZHAO X J, LIU B T, et al. Volumetric overall mass transfer coefficients of $\mathrm{CO}_{2}$ absorption into aqua ammonia in structured packed column[J]. Journal of Chemical Industry and Engineering, 2012, 63(4): 1102-1106(in Chinese).

[13] CHENG Z M, ZHU K H, YUAN W K. Advanced reaction engineering Tutorial[M]. Shanghai: East China University of Technology Press, 2010(in Chinese). 
[14] BLAUWHOFF P M M, VERSTEEG G F, VAN SWAAIJ W P M. A study on the reaction between $\mathrm{CO}_{2}$ and alkanolamines in aqueous solutions[J].Chemical Engineering Science, 1983,38(9): 1411-1429.

[15] JIANG W J, LEI L H, LIU M L, et al. Principles of Chemical Engineering (Volume 3) [M].Beijin: Tsinghua University Press, 2010(in Chinese).

[16] LI H, LIU Y S, ZHANG H, et al. Effect of reaction conditions on mass transfer performance of $\mathrm{CO}_{2}$ absorption by monoethanolamine Solution for biogas purification[J]. Transactions of the Chinese Society of Agricultural Machinery, 2015, 46(1):185-191(in Chinese).

[17] VERSTEEG G F, VAN SWAALJ W P M. Solubility and diffusivity of acid gases (carbon dioxide, nitrous oxide) in aqueous alkanol amine solutions[J]. Journal of Chemical and Engineering Data, 1988, 33(1):29-34.

[18] QI G J, WANG S J, LIU J Z, et al. Impact of $\mathrm{SO}_{2}$ on $\mathrm{CO}_{2}$ capture in coal-fired flue gas using aqueous ammonia[J]. Journal of Chemical Industry and Engineering, 2012, 63(7): 2203-2209(in Chinese).

[19] LUO P, XIE Q B. The solubility study of $\mathrm{Ca}(\mathrm{OH})_{2}$ "anomaly"[J]. Chemistry Teaching and Learning, 2014(5):72-73(in Chinese). 